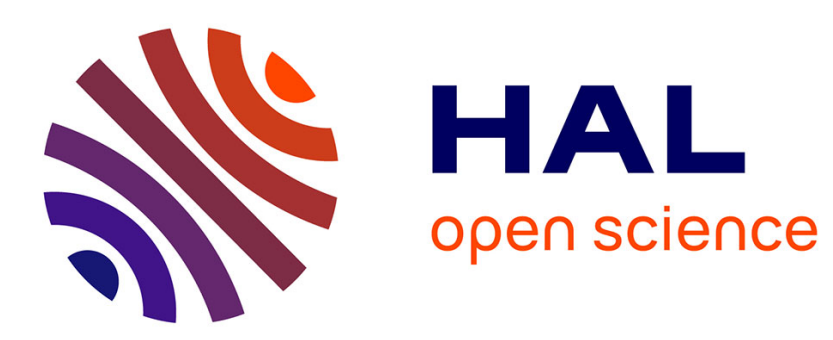

\title{
Seasonal changes in plasma levels of gonadal steroids of sea Bass Dicentrarchus labrax
}

\author{
F. Prat, S. Zanuy, M. Carillo, A. de Mones, Alexis Fostier
}

\section{To cite this version:}

F. Prat, S. Zanuy, M. Carillo, A. de Mones, Alexis Fostier. Seasonal changes in plasma levels of gonadal steroids of sea Bass Dicentrarchus labrax. General and Comparative Endocrinology, 1990, 78, pp.361-373. 10.1016/0016-6480(90)90026-I . hal-02715257

\section{HAL Id: hal-02715257 \\ https://hal.inrae.fr/hal-02715257}

Submitted on 1 Jun 2020

HAL is a multi-disciplinary open access archive for the deposit and dissemination of scientific research documents, whether they are published or not. The documents may come from teaching and research institutions in France or abroad, or from public or private research centers.
L'archive ouverte pluridisciplinaire HAL, est destinée au dépôt et à la diffusion de documents scientifiques de niveau recherche, publiés ou non, émanant des établissements d'enseignement et de recherche français ou étrangers, des laboratoires publics ou privés. 


\title{
Seasonal Changes in Plasma Levels of Gonadal Steroids of Sea Bass, Dicentrarchus labrax L.
}

\author{
F. Prat, S. Zanuy, M. Carrillo, A. De Mones, ${ }^{*}$ and A. Fostier* \\ Instituto de Acuicultura de Torre de la Sal, Ribera de Cabanes 12595, Castellón, Spain, and ${ }^{*}$ Laboratoire de \\ Physiologie des Poissons, INRA, Campus de Beaulieu, 35042 Rennes, Cédex, France
}

Accepted July 19, 1989

\begin{abstract}
Levels of plasma testosterone (T) and 11-ketotestosterone (11-KT) in males and plasma

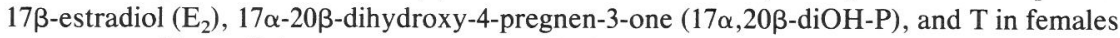
were assayed by radioimmunoassay at monthly intervals throughout the sexual cycle of sea bass (Dicentrarchus labrax L.). 17a,20ß-DiOH-P was maintained at low levels (below 1 $\mathrm{ng} / \mathrm{ml}$ ) throughout the year, even during the spawning period (January-March). A bimodal seasonal pattern of plasma testosterone was observed. Plasma $T$ and $E_{2}$ levels became significantly increased in December (advanced gametogenesis period) and then showed further increases during January and February (first half of the spawning period) in parallel with the growth of the vitellogenic oocytes. Multiple spawnings of individual females were also observed during the spawning period affecting the relative fecundity of the eggs. A possible role of $\mathrm{E}_{2}$ on this behavior is discussed. In males, both plasma T and 11-KT initially increased in November and then showed further increasings during the rest of the period of gametogenesis (December) to reach their peak levels in the first half of the spawning period (end of January). These increased and sustained higher levels of plasma steroids coincided with the presence of spermiating males. A second peak of plasma testosterone appeared at the end of the postspawning period-beginning of the pregametogenesis period (May-June) both in males and females and their possible role with the preparation of the gonad for the next reproductive cycle is discussed. 1990 Academic Press, Inc.
\end{abstract}

In recent years, sea bass, a highly prized fish, has received considerable attention from scientists and aquaculturists with the aim of improving the efficiency of its culture. The control of reproduction is of a particular interest. Knowledge of the role of sex steroids in controlling the maturation cycle in sea bass, especially when spawning time is altered by environmental or hormonal manipulation, is of both theoretical and practical interest.

Seasonal changes in serum gonadal steroid hormone levels have been well documented in a number of freshwater teleost species (Fostier et al., 1983). Less information is available for marine species, although seasonal changes in androgens and/ or estrogens have been reported in flatfish (Campbell et al., 1976; Wingfield and Grimm, 1977), black goby (Bonnin, 1979), bluefish and king mackerel (MacGregor et al., 1981), striped mullet (Dindo and MacGregor, 1981), Staghorn sculpin (de Vlaming et al., 1984), Sparus aurata (Kadmon et al., 1985), Rhabdosargus sarba (Yeung and Chan, 1987), blue cod (Pankhurst and Conroy, 1987), and red seabream (Duchi et al., 1988a, b).

Generally, more interest has been focused on the rapid changes which accompany final gonadal maturation in these fish (Goetz et al., 1987; Scott and Canario, 1987; Hirose et al., 1987; Adachi et al., 1988). Various differences have emerged between some marine and freshwater species. In two marine perciform fishes (Trant et al., 1986; Thomas et al., 1987), $17 \alpha, 20 \beta$-dihydroxy-4-pregnen-3-one, the claimed maturation induction steroid (MIS) for salmonids (Fostier and Jalabert, 1982; 
Goetz, 1983), is low and does not change significantly during final oocyte maturation. Furthermore, data from $S$. aurata, a multispawner, show high levels of plasma $17 \beta$-estradiol $\left(\mathrm{E}_{2}\right)$ during the spawning season (Kadman et al., 1985).

The sea bass, Dicentrarchus labrax L., is a marine teleost that reproduces annually upon reaching sexual maturity. Although histological aspects of the gonads and spawning are well documented for this species (Caporiccio, 1976; Barnabé, 1980; Brusle and Roblin, 1984; Zanuy et al., 1986; Mayer et al., 1988; Carrillo et al., 1989a), apart from Prat et al. (1985) very little is known about seasonal levels of circulating gonadal steroids. It is also not clear whether this species undergoes multiple spawnings in captivity. The purpose of the present study was to determine how serum estrogen, progestagen, and androgen concentrations change during seasonal reproduction and to determine if correlations exist among these changing levels, environmental factors, oocyte growth (based on oocyte diameters), number of spawnings, and fecundity.

\section{METHODS}

\section{Facilities}

Adult female $[1.07 \pm 0.085 \mathrm{~kg}($ mean \pm SEM $) ; 46.8$ $\pm 1.30 \mathrm{~cm}]$ and male $(0.89 \pm 0.054 \mathrm{~kg} ; 44.7 \pm 0.80 \mathrm{~cm})$ sea bass, bred within the facilities of the Instituto de Acuicultura de Torre de la Sal, were maintained in 12000-liter tanks, supplied with aerated running seawater, under natural conditions of photoperiod and temperature (Fig. 1).

\section{Sampling Procedure}

Fish were sampled monthly for 1 year. They were anesthetized in (100 ppm) MS-222 (Sigma), weighed, and measured. A 1-ml blood sample was taken from each fish by caudal puncture and the plasma was separated and stored at $-30^{\circ}$ until analysis. Males were checked for milt production by gentile abdominal massage, and females were sampled by cannulation from November to April in order to determine gonadal development (Zanuy et al., 1986; Carrillo et al., 1989a). In earlier months, females were not cannulated in or- der to avoid unnecessary damage to the developing gonadal ducts. Oocyte diameter was measured and the stages of maturation were assessed according to $\mathrm{Za}$ nuy et al., (1986). Eggs were collected from the outflow water of the tank in special fine gauge nets and the number of natural spawnings was recorded each day. Unfortunately, it was not possible to ascertain the exact number of spawnings which had been carried out by the individual female fish as the eggs from each tank were pooled in the outflow collection nets. The total number of eggs produced and the relative fecundity (i.e., the number of eggs/kg of postspawned female body weight) were recorded, as were the proportion of floating (good quality) to sinking (poor quality) eggs in a measuring cylinder of seawater. Sinking eggs included both infertile and damaged ova, whereas the floating group always had fertilization rates in excess of $90 \%$.

\section{Steroid Assays}

Steroids. Nonradioactive steroids to be used as standards were purchased from Sigma Chemical Co. (St. Louis, MO). Radiolabeled steroids $\left(\left[1,2,6,7-{ }^{3} \mathrm{H}\right]-\right.$ testosterone $(93 \mathrm{Ci} / \mathrm{mmol}),\left[1,2-{ }^{3} \mathrm{H}\right] 11$-ketotestosterone $(93 \mathrm{Ci} / \mathrm{mmol})$, and $\left[2,4,6,7-{ }^{3} \mathrm{H}\right]$ estradiol $(93 \mathrm{Ci} /$ mmol) were purchased from Amersham International (Amersham, England). Radiolabeled 17 $\alpha$-hydroxy $20 \beta$-dihydro-progesterone was prepared from $\left[1,2,6,7-{ }^{3} \mathrm{H}\right]-17 \alpha$-hydroxyprogesterone $(56 \mathrm{Ci} / \mathrm{mmol})$ (Amersham International) by reduction with $\mathrm{NaBH}_{4}$ according to Fostier et al. (1973).

Antisera. Anti-testosterone-3-carboxymethyl BSA; anti-17 $\beta$-hydroxyandrost-4-ene-3,11-dione-3-carboxymethyl BSA; anti-17 $\beta$-estradiol-6-carboximethyl BSA; and anti-17 $\alpha$-20 $\beta$-dihydroxy-4-pregnen-3-one-3carboxymethyl BSA were used as antigens to raise antisera in rabbits. Antisera dilutions for the assays was $1 / 3500$ for anti-testosterone, 1/7500 for anti11 -ketotestosterone, $1 / 2500$ for anti-17 $\beta$-estradiol, and $1 / 5700$ for anti-17 $\alpha$-hydroxy-20 $\beta$-dihydroxyprogesterone. The specificity of the antisera is shown in Table 1.

\section{Steroid Extraction and Chromatography}

Radiolabeled steroid $(0.1 \mathrm{ml})(2000 \mathrm{dpm})$ was added to $0.1 \mathrm{ml}$ of plasma for recovery. Samples were extracted twice with a cyclohexane:ethylacetate mixture $(1: 1, v / v)$. After evaporation of the solvent, the dry residue was redissolved in dichloromethane:methanol $(95: 5, v / v)$, and in order to purify the steroids these were transferred to a Sephadex LH-20 column $(12 \times$ $0.5 \mathrm{~cm}$ ) (Pharmacia Fine Chemicals). Elution was performed in the same solvent system. After purification, a further evaporation of the solvent was performed and the dry residues were dissolved in 0.35 or $0.5 \mathrm{ml}$ of 

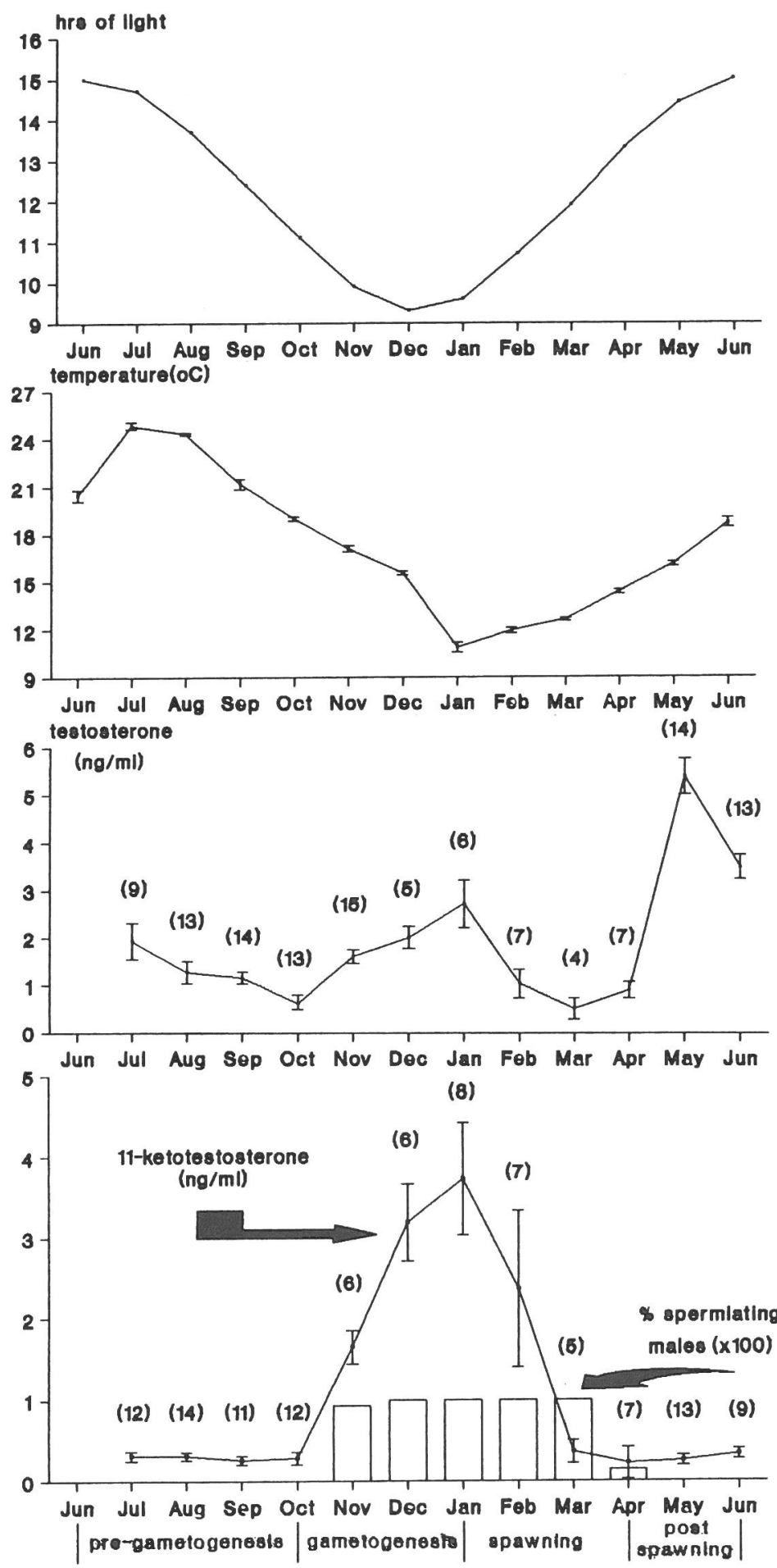

FIG. 1. Seasonal changes of plasma levels of testosterone and 11-ketotestosterone and percentage of spermiating males (white bars at the bottom) of male sea bass, kept under natural conditions of photoperiod and temperature. The number of fish per group is indicated in parentheses. Vertical bars represent means \pm SEM. Significant differences are reported in the text. 
TABLE 1

Specificity of the Antiserum Used in the AsSAys

\begin{tabular}{|c|c|c|}
\hline Antiserum & Steroid & $\begin{array}{c}\text { Cross-reaction } \\
(\%)\end{array}$ \\
\hline \multirow[t]{11}{*}{ Anti-testosterone $^{a}$} & Testosterone & 100.0 \\
\hline & 11-Ketotestosterone & 31.0 \\
\hline & $5 \alpha$-Dihydrotestosterone & 40.7 \\
\hline & Androstendione & 14.0 \\
\hline & $5 \alpha$-Androstan-3 $3,17 \beta$-diol & 2.2 \\
\hline & $5 \alpha-$ Androstan- $3 \alpha, 17 \beta$-diol & 6.2 \\
\hline & $11 \beta$-Hydroxyandrostendione & 0.2 \\
\hline & $11 \beta$-Hydroxytestosterone & $<0.1$ \\
\hline & Dehydroepiandrosterone & $<0.1$ \\
\hline & $17 \beta$-Estradiol & $<0.1$ \\
\hline & 17-Hydroxy-20ß-dihydroprogesterone & $<0.1$ \\
\hline \multirow[t]{11}{*}{ Anti-11-ketotestosterone ${ }^{a}$} & 11-Ketotestosterone & 100.0 \\
\hline & Testosterone & 1.4 \\
\hline & $11 \beta$-Hydroxytestosterone & 0.8 \\
\hline & $5 \alpha$-Androstan-17 $\beta$-ol-3-one & 0.7 \\
\hline & Dehydroepiandrosterone & $<0.1$ \\
\hline & Androstendione & $<0.1$ \\
\hline & Androsterone & $<0.1$ \\
\hline & $5 \alpha-$ Androstan-3 $\beta, 17 \beta$-diol & $<0.1$ \\
\hline & $5 \alpha$-Androstan-3 $\alpha, 17 \beta$-diol & $<0.1$ \\
\hline & $17 \beta$-Estradiol & $<0.1$ \\
\hline & $17 \alpha$-Hydroxy-20 $\beta$-dihydroprogesterone & $<0.1$ \\
\hline \multirow[t]{10}{*}{ Anti-17 $\beta$-estradiol $^{a}$} & $17 \beta$-Estradiol & 100.0 \\
\hline & Estrone & 3.1 \\
\hline & 6 -Ketoestradiol-17 $\beta$ & 2.9 \\
\hline & 16 -Ketoestradiol-17 $\beta$ & 2.8 \\
\hline & 16-Epiestriol & 1.9 \\
\hline & Estriol & 0.3 \\
\hline & $17 \alpha$-Estradiol & $<0.1$ \\
\hline & Testosterone & $<0.1$ \\
\hline & 11-Ketotestosterone & $<0.1$ \\
\hline & $17 \alpha$-Hydroxy-20 $\beta$-dihydroprogesterone & $<0.1$ \\
\hline \multirow[t]{12}{*}{ 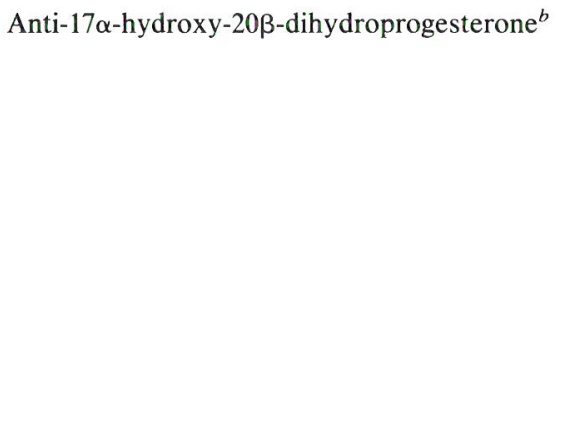 } & $17 \alpha$-Hydroxy-20 $\beta$-dihydroprogesterone & 100.0 \\
\hline & 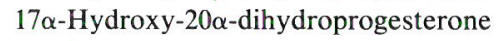 & 22.0 \\
\hline & $20 \beta$-Dihydroprogesterone & 34.0 \\
\hline & $5 \alpha$-Pregnan-3 $\alpha$-ol-20-one & 7.0 \\
\hline & Progesterone & $<0.1$ \\
\hline & $11 \alpha$-Hydroxyprogesterone & $<0.1$ \\
\hline & 11-Ketoprogesterone & $<0.1$ \\
\hline & $17 \alpha$-Hydroxyprogesterone & $<0.1$ \\
\hline & Testosterone & $<0.1$ \\
\hline & 11-Ketotestosterone & $<0.1$ \\
\hline & $17 \beta$-Estradiol & $<0.1$ \\
\hline & Estrone & $<0.1$ \\
\hline
\end{tabular}

${ }^{a}$ Cross-reaction expressed as the ratio (in percentage) between the amount of standard steroid and the amount of heterologous steroid required to produce $50 \%$ inhibition of binding.

${ }^{b}$ Cross-reaction expressed as the diminution in the proportion of displaced label produced by $1 \mathrm{ng} / \mathrm{tube}$ of heterologous steroid to that produced by the same amount of the standard steroid. 
buffer phosphate $\left(\mathrm{NaH}_{2} \mathrm{PO}_{4}, \mathrm{Na}_{2} \mathrm{HPO}_{4}, \mathrm{NaCl}\right)$ with gelatine, $\mathrm{pH} 7.25$.

\section{Assay}

Plasma levels of testosterone (T), 11-ketotestosterone (11-KT), 17 $\beta$-estradiol $\left(\mathrm{E}_{2}\right)$, and $17 \alpha-20 \beta$-dihydroxy-4-pregnen-3-one ( $17 \alpha-20 \beta$-diOH-P) were measured by radioimmunoassay according to Fostier $e t$ al. (1982) and Prat et al. (1986). All samples were assayed in duplicate, together with standard dilutions (5-1000 $\mathrm{pg} / 0.1 \mathrm{ml}$, in triplicate). Diluted antiserum $(0.1 \mathrm{ml})$ and $0.1 \mathrm{ml}$ of assay label $(20000 \mathrm{dpm} / 0.1 \mathrm{ml})$ were added to a $0.1-\mathrm{ml}$ extracted and chromatographed sample. After $3 \mathrm{hr}$ incubation at $20^{\circ}$, the bound steroids were precipitated overnight at $4^{\circ}$ by adding polyethyleneglycol (Merck) (PEG) (25\% in phosphate buffer). After centrifugation at $3200 \mathrm{rpm}$ for $40 \mathrm{~min}$ at $14^{\circ}$, the supernatant was discarded. The pellets were rinsed with PEG and centrifuged, and the supernatant was discarded. Pellets were redissolved in $0.1 \mathrm{ml}$ of ethanol. Scintillation fluid $(2.8 \mathrm{ml})$ (toulene, PPO $4 \mathrm{~g} /$ liter and POPOP $0.1 \mathrm{~g} /$ liter) was added for counting in a LKB Wallace 1212 Rack beta counter.

To calculate the steroid concentrations in the samples, a logit-log transformation was used and the levels were corrected for recovery.

Assay sensitivity for $\mathrm{T}, 11-\mathrm{KT}, \mathrm{E}_{2}$, and $17 \alpha, 20 \beta$ diOH-P ranged from 20 to $40 \mathrm{pg} /$ tube, 10 to $30 \mathrm{pg} / \mathrm{tube}$, 5 to $10 \mathrm{pg} /$ tube, and 10 to $20 \mathrm{pg} /$ tube, respectively. The intraassay ranges varied between 9.43 and $10.34 \%$ for T, 5.62 and $6.26 \%$ for $11-\mathrm{KT}$, and 8.41 and $10.39 \%$ for $\mathrm{E}_{2}$. The interassay variation was $9.43 \%(n=3), 9.46 \%$ $(n=3)$, and $15.03 \%(n=3)$ for T, 11-KT, and $\mathrm{E}_{2}$, respectively. The precision for $17 \alpha, 20 \beta$-diOH-P was not calculated because only very low concentrations were found.

\section{Statistics}

The statistical errors are expressed as the standard error of mean (SEM). The correlation coefficient was considered significant at the 5\% significance levels. One-way analysis of variance (ANOVA) was used to test for significant monthly changes between groups within a single treatment. If significant $(P<0.05)$, the Student-Newman-Keul's multiple range test was applied to compare mean levels at different sampling times. Bartlett's test was used to verify the homogeneity of variances. When variances were not homogeneous, data were log transformed before subjecting them to ANOVA.

\section{RESULTS}

\section{Plasma Testosterone}

Over the year of sampling the plasma tes- tosterone, both in males and in females, exhibited bimodal patterns levels. For males the first significant $(P<0.05)$ increase in plasma testosterone appeared in November and for females in December. The first peak occurred in January for males $(2.36 \pm 0.534$ $\mathrm{ng} / \mathrm{ml})$ and in February for females $(8.4 \pm$ $2.35 \mathrm{ng} / \mathrm{ml}$ ) (Figs. 1 and 2). T levels increased again significantly $(P<0.05)$ at the end of the postspawning period; the highest levels were registered in May for males and in June for females both postspawning (Figs. 1 and 2). Plasma T levels of females were significantly higher $(P<0.001)$ than those of males during the whole sexual cycle, except in July.

\section{Plasma 11-Ketotestosterone}

Plasma 11-KT concentrations were measured only in males, these exhibited a unimodal seasonal pattern. Baseline values were evident from March to October, i.e., at the end of the spawning period (March), and during the postspawning period (AprilMay), pregametogenesis period (JuneSeptember), and the beginning of the gametogenesis period (October). Levels of plasma 11-KT rose steadily and significantly from November to January $(P<$ 0.05 ), only to decrease in the second half of the spawning period (February-March) (Fig. 1).

\section{Plasma 17ß-Estradiol}

Low levels of plasma $E_{2}$ (around $2 \mathrm{ng} / \mathrm{ml}$ ) were observed from September to November in females; levels rose again at the end of gametogenesis period (December) and peaked in the middle of the spawning period (February) $(4.9 \pm 1.71 \mathrm{ng} / \mathrm{ml})$. A sharp decline was then observed. Baseline values $(<1 \mathrm{ng} / \mathrm{ml})$ were reached at the end of spawning period (March). High levels of plasma $E_{2}$ were observed in July and August during the first pregametogenesis period (Fig. 2). 


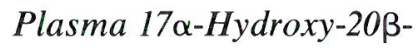
dihydroxyprogesterone

No significant monthly variations were exhibited by plasma levels of $17 \alpha, 20 \beta-$ diOH-P in females. Their values ranged from $0.10 \mathrm{ng} / \mathrm{ml}$ in January to $0.75 \mathrm{ng} / \mathrm{ml}$ in June with an annual mean value \pm SEM of $0.35 \pm 0.071 \mathrm{ng} / \mathrm{ml}$ (Fig. 2).

\section{Changing Egg Size, Buoyancy, and Relative Fecundity}

The changes in mean size oocytes are shown in Fig. 2. During the gametogenesis period and the first half of the spawning period there was a steady increase of mean oocyte diameter after which there was a significant decrease. The maximum size of intraovarian oocytes was observed during February $(672.8 \pm 12.61 \mu \mathrm{m})$. Percentage of floating and sinking eggs and relative fecundity of sea bass are shown in Fig. 2. Ten spawnings were registered from January 1 st to March 21st in a group of five females (average somatic weight $1.3 \pm 0.11 \mathrm{~kg}$ ). Around 3.5 million eggs were obtained of which $68.1 \%$ were viable. Average relative fecundity was $2.5 \times 10^{5} \mathrm{eggs} / \mathrm{kg}$ body weight, but if we take into account multiple spawnings this result could be significantly higher. Earlier spawnings (January) were of poor quality (Fig. 2). Spermiating males were observed from November to March (Fig. 1).

\section{DISCUSSION}

Gonadal ontogenesis, sex differentiation, and sexuality of sea bass have been described by Roblin and Bruslé (1983) and Bruslé and Roblin (1984) and the sexual cy- cle by Zohar et al. (1984), Mayer et al. (1988), and Carrillo et al. (1989a).

These studies and present results have allowed us to divide the sexual cycle of sea bass into four physiological stages mainly based on monthly frequency distributions of gamete type and size: (1) The pregametogenetic period that begins in June and ends in September. During this period gonads remain immature (Plate 1a and 1c). (2) period of gametogenesis which lasts from October to December. In October, some lipid droplets, cortical alveoli, and a small number of yolk globules appear in the oocyte cytoplasm. However, the bulk of yolk globules does not appear in the oocytes until November/December (Plate 1d). Spermiating males are observed throughout this period (Fig. 1, Plate 1b). (3) The spawning period starts in January and ends in March. During this period, ovaries are in the mature or postvitellogenic or postovulatory stages, although a significant proportion of oocytes in different stages of vitellogenesis are also observed. (4) The postspawning period. This developmental stage, which lasts from April to May, is characterized by a high percentage of atretic oocytes in the ovary and residual bodies in the testis.

The present study confirms earlier reports that sea bass spawn annually in winter in the Mediterranean sea, in general over the months of December to March (Barnabé, 1980; Zohar et al., 1984). Our results indicate that, although a transient spawning of poor quality eggs was produced during January, the bulk of spawnings occurred during February and March. Earlier spawnings have been reported but appear to depend on seawater temperatures

FIG. 2. Seasonal changes of plasma levels of testosterone, $17 \beta$-estradiol, and $17 \alpha, 20 \beta$-dihydroxyprogesterone, oocyte diameter, and relative fecundity (bars at the bottom) showing the number of viable (open bars) and unviable (black bars) eggs of female sea bass, kept under natural conditions of photoperiod and temperature. The number of fish per group is indicated in parentheses. Vertical bars are means \pm SEM with significant differences reported in the text. 

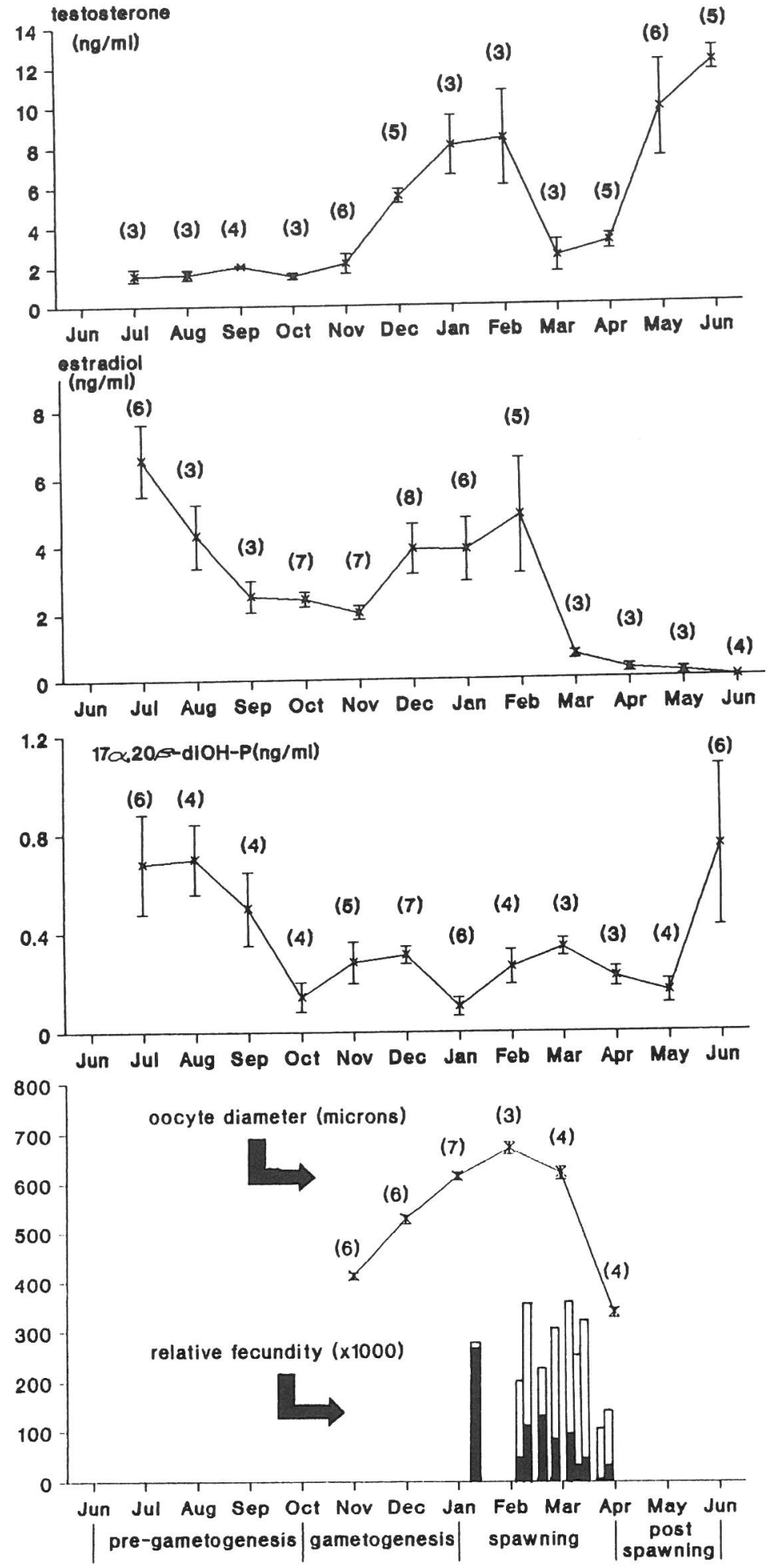

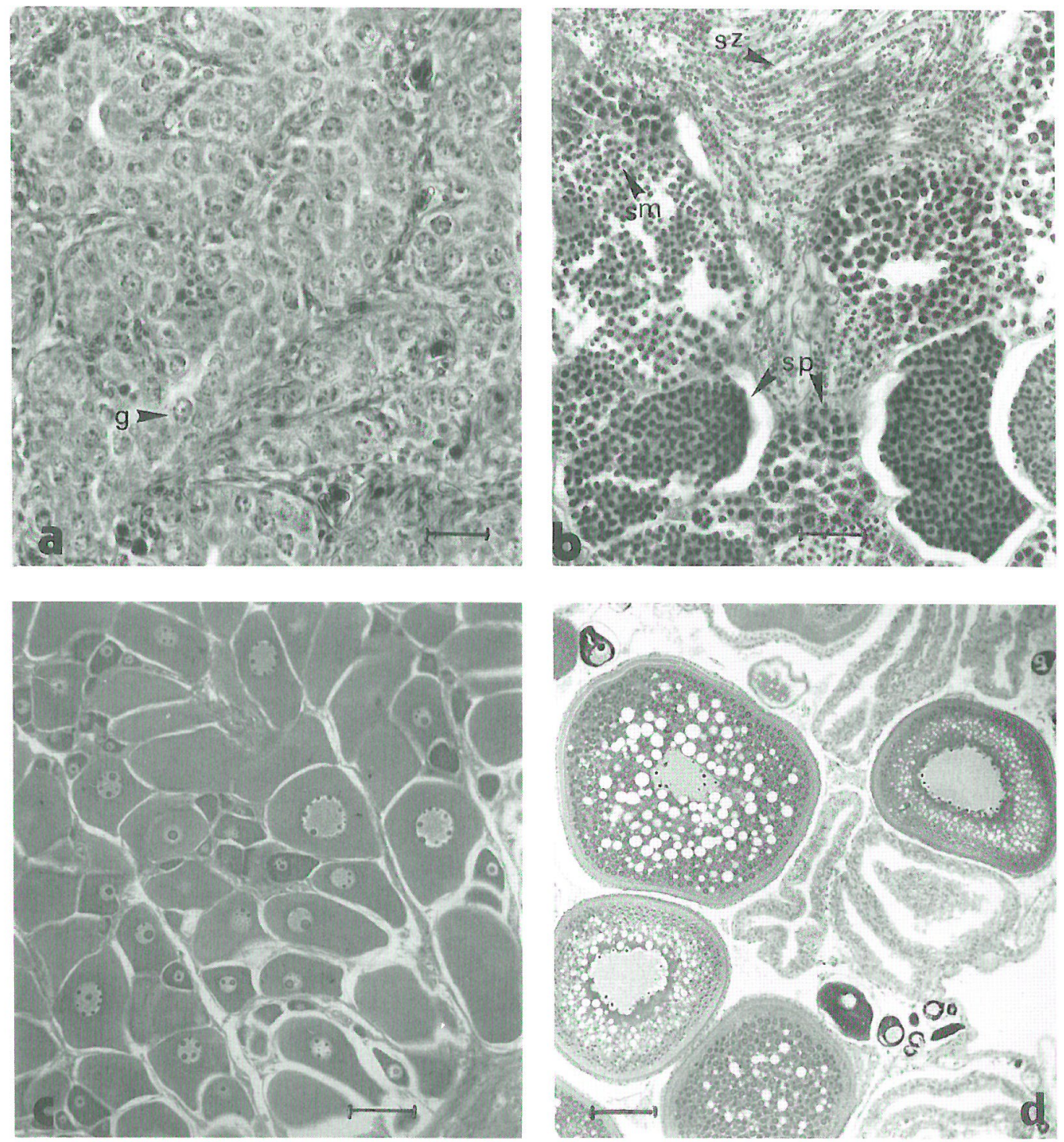

Plate 1. Sections of male and female gonads of sea bass (D. labrax L). (a) Immature testis in June showing spermatogonia. (b) Ripe testis in December containing germinal cells in different stages of gonadal development. g, spermatogonia; sp, primary and secondary spermatocytes; sm, spermatids; and sz, spermatozoa. (c) Immature ovary in August containing previtellogenic oocytes. (d) Mature ovary in December containing oocytes in different stages of vitellogenesis. $5 \mu \mathrm{m}$ plastic sections, Cleveland Wolfe. $\times 70 \mu \mathrm{m}$.

(Zanuy et al., 1986; Carrillo et al., 1989b). Males produced milt 2 months before the first spawning of females took place. This agrees with the histological observations made on male sea bass by Ch. Cauty, R.
Billard, and G. Barnabé, (unpublished results) quoted by Zohar et al. (1984).

It has been stated that both in nature and in captivity the sea bass is a group synchronous fish in which each female spawns once 
a year (Barnabé, 1980). The present results and those recently presented by Zanuy et al. (1986) and Carrillo et al. (1989a) clearly show that individual females in captivity can spawn more than once during the spawning season. Multiple spawning has profound influences on the apparent relative fecundity of the sea bass, giving values over the spawning period as high as 530,000 eggs $/ \mathrm{kg}$, instead of $265,000 \mathrm{egg} / \mathrm{kg}$ if each female spawns twice as an average. Quality of spawnings was also high (76.4\% of viable eggs, if January spawning is excluded). Similar high fecundities for sea bass have already been described by Bou Ain (1977) and Carrillo et al. (1989a).

In females, the parallel changes of testosterone, $\mathrm{E}_{2}$, and oocyte diameter peaked 1 month behind the T and 11-KT plasma levels observed in males during the spawning period. The distinct hormonal differences between males and females during the reproductive period fits well with the differences found in the duration of the spawning period of the two sexes (Figs. 1 and 2).

Plasma levels of $\mathrm{T}$ showed a bimodal increase during the sexual cycle in both sexes. This bimodality has been observed in other teleosts (Bonnin, 1979, Burke et al., 1984; Pankhurst and Conroy, 1987), although its significance is not clear.

Plasma levels of $\mathrm{T}$ in sea bass were higher in females than in males. Similar results have been obtained in other teleosts, especially during vitellogenesis (Campbell et al., 1976, 1980; Stuart-Kregor et al., 1981; Scott et al., 1980a, b). It has been stated that androgens are the precursors of estrogens, and that the former are released into the plasma when no longer needed for aromatization (Campbell et al., 1976). On the other hand, several authors have observed good correlation among plasma $\mathrm{E}_{2}$ levels, gonadosomatic index, and oocyte size during the period of vitellogenesis (Wingfield and Grimm, 1977; Lambert et al., 1978; Crim and Idler, 1978; Kagawa et al., 1983; Breton et al., 1983; Schulz, 1984). In agree- ment with these facts, we have also observed a positive correlation of plasma $\mathrm{T}$ and $E_{2}$ with the evolution of oocyte diameter during the gametogenesis period and the spawning period. These results suggest that $\mathrm{E}_{2}$ is involved in the vitellogenin synthesis during vitellogenesis and that the production of $E_{2}$ is dependent on $T$.

High levels of $T$ and $E_{2}$ were also observed during the spawning period coinciding with the maximum oocyte diameter as determined from biopsies of ovary. Similar patterns have also been observed in Acheilognathus rhombea (Shimuzu et al., 1987), goldfish (Kagawa et al., 1983), and also in Sparus aurata (Kadmon et al., 1985) which like the sea bass spawns several times (during each spawning season). Present results show that sea bass can also spawn several times during the spawning period and it is likely that the typical pattern of $E_{2}$ changes observed could be related with this spawning behavior and to the developmental stages of groups of oocytes in their ovaries in a similar way as in those teleosts already mentioned. More specifically, sea bass ovary contains vitellogenic oocytes after ovulation, as has also been observed by Carrillo et al. (1989a). $\mathrm{E}_{2}$ in the plasma of sea bass during spawning can be accounted for the production of this steroid by the remaining vitellogenic follicles.

The lowest levels of $E_{2}$ and a significant decrease of oocyte diameter during March suggest that vitellogenesis terminates immediately at the end of the spawning period. A maximum proportion of ovulated oocytes is also observed at this time (data not shown).

The failure of $17 \alpha, 20 \beta$-diOH-P to show seasonal changes in female sea bass is of the special interest, as this progestagen has been shown to be the most active steroid in inducing in vitro oocyte maturation in a number of teleosts (see reviews in Fostier and Jalabert, 1982; Goetz, 1983; Scott and Canario, 1987), and in vivo peaking in the 
plasma during germinal vesicle breakdown or ovulation in salmonids (Goetz et al., 1987). Colombo et al. (1978) showed that despite the pattern of steroidogenesis in sea bass, gonads changed with the reproductive state and that ovulating sea bass produce 21-hydroxylated pregnanes. They did not find any $17 \alpha, 20 \beta$-dihydroxy-4-pregnen3 -one in the gonads of this species. In agreement with these results, we also did not find measurable changes in plasma levels of $17 \alpha, 20 \beta$ di-OH-P in sea bass during the spawning period. This can suggest, as they were put forward by Scott and Canario (1987), that this progestagen is not the MIS in this species, that the plasma levels change over a short time span, or more likely that the hormone may be in conjugated form as has been recently found in this species (Scott et al., 1990). Some other marine species also do not show either significant changes of plasma $17 \alpha, 20 \beta-\mathrm{diOH}-\mathrm{P}$ in asynchronous fish undergoing final oocyte maturation (Pankhurst and Conroy, 1987; Thomas et al., 1987; Trant and Thomas, 1987) or synchronous fish (Pankhurst and Conroy, 1988). A novel MIS, 17 $\alpha, 20 \beta$,21-trihydroxy-4-pregnen-3-one (20ß-S), has been identified in some perciform fishes (Trant et al., 1986; Thomas et al., 1987). This steroid, which was the predominant $\mathrm{C} 21$, has also been found, both in free and in congugated form, in the plasma of sea bass during induced ovulation (P. Thomas, S. Zanuy, M. Carrillo, and F. Prat, unpublished data; Scott et al., 1990. These results suggest that $20 \beta-S$ may also participate in the natural induction of final oocyte maturation in a similar way as has been observed in other marine perciform fishes.

The presence of spermiating males coincided with the surge of both plasma $\mathrm{T}$ and $11-\mathrm{KT}$. This increase lasted during most of the period of gametogenesis and spawning. In this case the role of the 11-KT in sea bass could be related more with the initiation of spermiation since the final stages of maturation is regulated by $\mathrm{C} 21$ steroids in most, if not all, teleosts so far investigated (Fostier et al., 1982, 1987).

The second peak of $\mathrm{T}$ observed at the end of the postspawning period-beginning of the pregametogenesis period was higher than the one observed during the spawning period but was not correlated with 11-KT plasma levels in males or $\mathrm{E}_{2}$ in females. $\mathrm{T}$ may play a different role in reproductive development at the end of the postspawning period. This peak could be related with the positive feedback effect of steroids stimulating synthesis and accumulation of GTH in the pituitary as observed in immature fish (Billard et al., 1978; Crim and Evans, 1979). This could be the initial step in the preparation of the gonad for the next reproductive cycle.

\section{ACKNOWLEDGMENTS}

We thank R. Serrano for processing spawning data and R. Simó and J. M. Llorens for their technical assistance during sampling and stocking of fish. This study was supported by a research grant to Dr. M. Carrillo (No. 3/83) from the CAICYT and from a French-Spanish Joint Research Programe (No. 6/168).

\section{REFERENCES}

Adachi, S., Ouchi, K., Hirose, K., and Nagahama, Y. (1988). Induction of oocyte maturation in vitro by steroid hormones in the red sea bream Pagrus major. Nippon Suisan Gakkaishi 54,(9), 1665.

Barnabé G. (1980). Exposé synoptique des données biologiques sur le loup ou bar-Dicentrarchus labrax (Linné, 1758). Synopsis FAO sur les pêches 126, $1-70$.

Billard, R., Breton B., Fostier, A., Jalabert, B., and Weil, C. (1978). Endocrine control of the teleost reproductive cycle and its relation to external factors: Salmonid and cyprinid models. In "Comparative Endocrinology" (P. J. Gaillard and H. H. Boer, Eds.), pp. 37-48. Elsevier/North-Holland, Amsterdam.

Bonnin, J. P. (1979). Variations saisonnières de la testostérone plasmatique chez un poisson téléostéen, Gobius niger. C.R. Hebd. Seances Acad. Sci. Ser. D. 288, 627-630.

Bou Ain, A. (1977). "Contribution à l'étude morphologique, anatomique et biologique de Dicentrarchus labrax (Linné, 1758) et Dicentrarchus 
punctatus (Bloch, 1792) des côtes tunisiennes." Thèse de doctorat de spécialité, Faculté des Sciences, Tunis.

Breton, B., Fostier, A., Zohar, Y., Le Bail, P. Y., and Billard, R. (1983). Gonadotropin glycoproteique et estradiol-17 $\beta$ pendant le cycle reproducteur chez la truite fario (Salmo trutta) femelle. Gen. Comp. Endocrinol. 49, 220-231.

Bruslé, J., and Roblin, C. (1984). Sexualité du loup, Dicentrarchus labrax en condition d'élevage controlé. In "L'Aquaculture du bar et des Sparidés", (G. Bernabé and R. Billard, Eds.), pp. 83-44. INRA Publications, Paris.

Burke, M. G., Leatherland, J. F., and Sumpter, J. P. (1984). Seasonal changes in serum testosterone, 11-ketotestosterone, and 17ß-estradiol levels in the brown bullhead, Ictalurus nebulosus Lesueur. Canad. J. Zool. 62, 1195-1199.

Campbell, C. M., Walsh, J. M., and Idler, D. R. (1976). Steroids in the plasma of the winter flounder Pseudopleuronectes americanus Walbaum: A seasonal study and investigation of steroid involvement in oocyte maturation. Gen. Comp. Endocrinol. 29, 14-20.

Campbell, C. M., Fostier, A., Jalabert, B., and Truscott, B. (1980). Identification and quantification of steroids in the serum of spermiating or ovulating rainbow trout. J. Endocrinol. 85, 371378.

Caporicco, B. (1976). Etude ultrastructurale et cytochoimique de l'ovogenese du loup (Dicentrarchus labrax L.). Thesis. Université des Sciences et Techniques du Languedoc.

Carrillo, M., Bromage, N. R., Zanuy, S., Serrano, R., and Prat, F. (1989a). The effect of modifications in photoperiod on spawning time, ovarian development and egg quality in the sea bass (Dicentrarchus labrax L.). Aquaculture 81, 351-365.

Carrillo, M., Zanuy, S., Prat, F., Serrano, R., and Bromage, N. (1989b). Environmental induction of spawning in sea bass. In "Proceedings, Satellite Symp. Applicat. Comp. Endocrinol. Fish Culture"' (M. Carrillo, S. Zanuy, and J. Planas, compilers), pp. 33-43. PUB. Almuñecar (Granada), Spain.

Colombo, L., Colombo Belvedere, P., and Arcarese, G. (1978). Emergence of ovarian 11-deoxycorticosteroid biosynthesis at ovulation time in the sea bass, Dicentrarchus labrax L. Ann. Biol. Anim. Biochim. Biophys. 18, 937-941.

Crim, L. W., and Evans, D. M. (1979). Stimulation of pituitary gonadotropin by testosterone in juvenile rainbow trout (Salmo gairdneri). Gen. Comp. Endocrinol. 37, 192-196.

Crim, L. W., and Idler, D. R. (1978). Plasma gonadotropin, estradiol, and vitellogenin and gonad phosvitin levels in relation to the seasonal reproduc- tive cycles of female brown trout. Ann. Biol. Anim. Biochim. Biophys. 18, 1001-1005.

de Vlaming, V. L., Fitzgerald, R., Delahunty, G., Cech, J. J., Selman, K., and Barkley, M. (1984). Dynamics of oocyte development and related changes in serum estradiol-17 $\beta$, yolk precursor, and lipid levels in the teleostean fish, Leptocottus armatus. Comp. Biochem. Physiol. A. 77(4), 599610.

Dindo, J. J., and MacGregor, R., III (1981). Annual cycle of serum gonadal steroids and serum lipids in stripped mullet. Trans. Amer. Fish Soc. 110 403-409.

Fostier, A., Billard, R., Breton, B., Legendre, M., and Marlot, S. (1982). Plasma 11-oxotestosterone and gonadotropin during the beginning of spermiation in rainbow trout (Salmo gairdneri R.). Gen. Comp. Endocrinol. 46, 428-434.

Fostier, A., and Jalabert, B. (1982). Physiological basis of practical means to induce ovulation in fish In "Proceedings, Intern. Symp. Reprod. Physiol. Fish"' (C. J. J. Richter and H. J. Th. Goos, Eds.), pp. 164-173. Pudoc, Wageningen, The Netherlands.

Fostier, A., Jalabert, B., Billard, R., Breton, B., and Zohar, Y. (1983). The gonadal steroids. In "Fish Physiology" (W. S. Hoar, D. J. Randall, and E. M. Donaldson, Eds.), Vol. 1XA, pp. 277-372. Academic Press, New York.

Fostier, A., Jalabert, B., and Terqui, M. (1973). Action prédominante d'un dérivé hydroxylé de la progestérone sur la maturation in vitro des ovocytes de la trute arc-en-ciel, Salmo gairdneri. C.R. Acad. Sci. Paris Ser. D. 277, 421-424.

Fostier, A., Le Gac, F., and Loir, M. (1987). Steroids in male reproduction. In "Proceedings of the Third International Symposium on the Reproductive Physiology of Fish", (D. R. Idler, L. W. Crim, and J. M. Walsh, Eds.). St. John's, Newfoundland, Canada.

Goetz, F. W. (1983). Hormonal control of oocyte final maturation and ovulation in fishes. In "Fish Physiology", (W. S. Hoar, D. J. Randall, and E. M. Donaldson, Eds.), Vol. IXB, pp. 117-170. Academic Press, New York.

Goetz, F. W., Fostier A., Breton, B., and Jalabert, B. (1987). Hormonal changes during meiotic maturation and ovulation in the brook trout (Salvelinus fontinalis). Fish Physiol. Biochem. 3, 203-211.

Hirose, K., Ouchi, K., Adachi, S., and Nagahama, Y. (1987). Role of steroid hormones in ovarian maturation in Japanese flounder. In "Proceedings, Third Inter. Symp. Reprod. Physiol. Fish”' (D. R. Idler, L. W. Crim, and J. M. Walsh, Eds.), pp. 257-258. St. John's, Newfoundland, Canada.

Kadmon, G., Yaron, Z., and Gordin, H. (1985). Sequence of gonadal events and oestradiol levels in 
Sparus aurata (L.) under two photoperiod regimes. J. Fish Biol. 26, 609-620.

Kagawa, H., Young, G., and Nagahama, Y. (1983). Changes in plasma steroid hormone levels during gonadal maturation in female goldfish, Carassius auratus. Bull. Japan. Soc. Sci. Fish. 49, 17831787.

Lambert, J. G. D., Bosman, G. I. C. G. M., van den Hurk, R., and van Dordt, P. G. W. J. (1978). Annual cycle of plasma estradiol-17 $\beta$ in the female trout Salmo gairdneri. Ann. Biol. Anim. Biochim. Biophys. 18, 923-927.

MacGregor, R., III, Dindo, J. J., and Finucane, J. H. (1981). Changes in serum androgens and estrogens during spawning in bluefish, Potmatomus saltator, and king mackerel, Scomberomorus cavalla. Canad. J. Zool. 59, 1749-1754.

Mayer, I., Shackley, S. E., and Ryland, J. S. (1988). Aspects of the reproductive biology of the bass, Dicentrarchus labrax L. I: An histological and histochemical study of oocyte development. $J$. Fish Biol. 33, 609-622.

Ouchi, K., Adachi, S., and Nagahama, Y. (1988a). Changes in plasma levels of steroid hormones during sexual maturation of female red seabream $\mathrm{Pa}$ grus major. Nippon Suisan Gakkaishi 54(4), 585591.

Ouchi, K., Adachi, S., and Nagahama, Y. (1988b). Changes in plasma levels of steroid hormones during sexual maturation of male red seabream $\mathrm{Pa}$ grus major. Nippon Suisan Gakkaishi 54(4), 593 597.

Pankhurst, N. W., and Conroy, A. M. (1987). Seasonal changes in reproductive condition and plasma levels of sex steroids in the blue cod, Parapercis colias (Bloch and Schneider) (Mugiloididae). Fish Physiol. Biochem. 4(1), 15-26.

Pankhurst, N. W., and Conroy, A. M. (1988). Endocrine changes during gonadal maturation and spawning in the orange roughy (Hoplostethus atlanticus Collet), a teleost from the midslope waters off New Zealand. Gen Comp. Endocrinol. 70, 262-273.

Prat, F., Carrillo, M., Zanuy, S., and Fostier, A. (1985). Fluctuations of plasma levels of testosterone and 11-ketotestosterone in males and $17 \beta$-estradiol in females of sea bass (Dicentrarchus labrax L.) along the year. In "7th Conference of European Society for Comparative Physiology and Biochemistry: Fish Culture," PPU., Barcelona. [Abstracts]

Prat, E., Carrillo, M., and de Mones, A. (1986). Validación del radioinmunoensayo para la estimación de la testosterona, 11-cetotestosterona y $17 \beta$-estradiol en plasma de lubina (Dicentrarchus labrax L.). Invest. Pesq. 50(2), 279-295.
Roblin C., and Bruslé, J. (1983). Ontogenèse gonadique et différenciation sexuelle du loup Dicentrarchus labrax, en conditions d'élevage. Reprod. Nutr. Dév. 23(1), 115-127.

Schulz, R. (1984). Serum levels of 11-oxotestosterone in male and $17 \beta$-estradiol in female rainbow trout (Salmo gairdneri) during the first reproductive cycle. Gen. Comp. Endocrinol. 56, 111-120.

Scott, A. P., Bye, V. J., and Baynes, S. M. (1980b). Seasonal variations in sex steroids of female rainbow trout, Salmo gairdneri Richardson. J. Fish Biol. 17, 587-592.

Scott, A. P., Bye, V. J., Baynes, S. M., and Springate, J. R. C. (1980a). Seasonal variations in plasma concentrations of 11-ketotestosterone and testosterone in male rainbow trout, Salmo gairdneri Richardson. J. Fish. Biol. 17, 495-505.

Scott, A. P., and Canario, A. V. M. (1987). Status of oocyte maturation-inducing steroids in teleosts. In "Proceedings, Third Intern. Symp. Reprod. Physiol. Fish" (D. R. Idler, L. W. Crim, and J. M. Walsh, Eds.), pp. 224-234. St John's, Newfoundland, Canada.

Scott, A. P., Canario, A. V. M., and Prat, F. (1990). Radioimmunoassay of ovarian steroids in plasmas of ovulating female sea bass (Dicentrarchus labrax). Gen. Comp. Endocrinol., in press.

Shimizu, A., Aida, K., and Hanyu, I. (1987). Annual reproductive cycle in an autumn spawning bitterling Acheilognathus rhombea. Nippon Suisan Gakkaishi 53(4), 529-536.

Stuart-Kregor, P. A. C., Sumpter, J. P., and Dodd, J. M. (1981). The involvement of gonadotropin and sex steroids in the control of reproduction in the parr and adults of Atlantic salmon, Salmo salar L. J. Fish Biol. 18, 59-72.

Thomas, P., Brown, N. J., and Trant, J. M. (1987). Plasma levels of gonadal steroids during the reproductive cycle of the spotted seatrout (Cynoscion nebulosus). In "Proceedings of the Third International Symposium on the Reproductive Physiology of Fish", (D. R. Idler, L. W. Crim, and J. M. Walsh, Eds.) St. John's, Canada.

Trant, J. M., and Thomas, P. (1987). The production of a novel maturation inducing steroid in vitro in the atlantic croaker Micropogonias undulatus. In "Proceedings of the Third International Symposium on the Reproductive Physiology of Fish", (D. R. Idler, L. W. Crim, and J. M. Walsh, Eds.), St. John's, Canada.

Trant, J. M., Thomas, P., and Shackleton, C. H. L. (1986). Identification of $17 \alpha, 20 \beta, 21$-trihydroxy4-pregnen-3-one as the major ovarian steroid produced by the teleost Micropogonias undulatus during final oocyte maturation. Steroids 47, 8999.

Wingfield, J. C., and Grimm, A. S. (1977). Seasonal 
changes in plasma cortisol, testosterone and oestradiol-17 $\beta$ in the plaice, Pleuronectes platessa L. Gen. Comp. Endocrinol. 31, 1-11.

Yeung, W. S. B., and Chan, S. T. H. (1987). A radioimmunoassay study of the plasma levels of sex steroids in the protandrous, sex-reversing fish Rhabdosargus sarba (Sparidae). Gen. Comp. Endocrinol. 66, 353-363.

Zanuy, S., Carrillo, M., and Ruiz, F. (1986). Delayed gametogenesis and spawning of sea bass (Dicen- trarchus labrax L.) kept under different photoperiod and temperature regimes. Fish Physiol. Biochem. 2(1-4), 53-63.

Zohar, Y., Billard, R., and Weil C. (1984). La reproduction de la daurade (Sparus aurata) et du bar (Dicentrachus labrax): Conaissance du cycle sexuel el contrôle de la gamétogenèse et de la ponte. In "L'Aquaculture du bar et des Sparidés" (G. Barnabé and R. Billard, Eds.), pp. 3-24. INRA Publications, Paris. 
